\title{
Quartz ceramics modified by nanodispersed silica additive
}

\author{
E.S.Khomenko, A.V.Zaichuk, E.V.Karasik, A.A.Kunitsa \\ State Higher Educational Establishment "Ukrainian State University of \\ Chemical Engineering", 8 Haharin Ave., 49005 Dnipro, Ukraine
}

Received February 19, 2018

\begin{abstract}
The article considers one of the ways to improve physical and technical characteristics of Quartz Ceramics. The method consists in adding the sintering activator into the quartz ceramic composition, i.e. Nanodispersed Silicon Dioxide obtained by means of sol-gel method based on Ethyl Silicate or Tetraethoxysilane. The amount of the additive amounts to 10 wt. $\%$. Samples containing the activator absorb water $40-45 \%$ less than the samples without activator, while the mechanical strength is increasing by 1.2-1.3 times. Moreover, this activator prevents the formation of Cristobalite phase being undesirable in the Quartz Ceramics.
\end{abstract}

Keywords: Quartz Ceramics, slurry, Ethyl Silicate, sol-gel, calcination, Cristobalite, firing, water absorption ability, mechanical performance.

Рассмотрен один из способов повышения физико-технических характеристик кварцевой керамики. Способ заключается во введении в состав кварцевой керамики активатора спекания - нанодисперсного кремния диоксида, полученного золь-гель способом на основе этилсиликата или тетраэтоксисилана. Количество добавки составляет 10 мас.\%. Образцы, содержащие активатор, имеют водопоглощение на 40-45 \% меньше по сравнению с образцами без активатора, при этом механическая прочность возрастает в 1,2-1,3 раза. Кроме того, данный активатор предупреждает формирование нежелательной в кварцевой керамике кристобаллитовой фазы.

Кварцова кераміка, модифікована добавкою нанодисперсного кремнезему. О.С.Хoменко, О.В.Зайчук, О.В.Карасик, А.А.Куниия.

Розглянуто один із способів підвищення фізико-технічних характеристик кварцової кераміки. Спосіб полягає у введенні до складу кварцової кераміки активатора спікання - нанодисперсного кремнію діоксиду, отриманого золь-гель способом на основі етилсилікату або тетраетоксисилану. Кількість добавки становить 10 мас.\%. Зразки, що містять активатор, мають водопоглинання на 40-45\% менше у порівнянні із зразками без активатора, при цьому механічна міцність зростає в 1,2-1,3 рази. Крім того, даний активатор попереджає формування небажаної у кварцовій кераміці кристобалітової фази.

\section{Introduction}

Among ceramic materials and technical products, Quartz Ceramics plays a significant role due to the presence of a complex of high physical and technical indicators. It is used as refractory material for general and special purposes, as a component material of products for rocket and space equip- ment and nuclear power engineering, as a component material of crucibles for metal heating and in a number of other areas [1,2].

Quartz Ceramics are usually produced using traditional ceramic processing technology by means of aqueous slurry casting, using affordable and inexpensive raw materials (Quartz Glass Scrap). The main disadvantage of products made of the Quartz Ce- 
ramics is their high water absorption ability (up to $15 \%$ ), which does not allow to reach the necessary mechanical strength indicators [3]. Intensive sintering of the semi-finished product should be ensured to increase the mechanical strength indicators; but this requires firing temperatures much higher than $1200^{\circ} \mathrm{C}$. At the same time, provided by the intense sintering temperature range, the Quartz Ceramics have an undesirable tendency to crystallize the Cristobalite phase and it results in worsening of already low strength characteristics of the finished products, and also significantly reduces their thermal stability.

There are various ways to eliminate these shortcomings. Thus, the work [4] establishes that it would be appropriate to perform the Quartz Ceramics reducing firing, which makes it possible to shift the process of its cristobalization to the higher temperature ranges (above $1350^{\circ} \mathrm{C}$ ) and achieve a better sintering effect without significant deterioration of thermal-physical properties.

To reduce the Quartz Ceramics pore content, some researchers [5-7] have proposed to use an additional operation of modifying its structure by treating the semi-finished products or fired products with various organosilicon binders. Implementation of such methods requires additional resource and energy expenses and yet it does not always allow to achieve the high properties of Quartz Ceramics.

There is an alternative to the above-mentioned methods, i.e. the Quartz Ceramics modification by Nanodispersed Silica additive by means of sol-gel method. The sol-gel method has found industrial application in the production of some types of technical ceramics [8] and provides getting sol of a certain chemical composition, in which the components are averaged at the molecular level. The system in the form of a sol transmits into a gel, i.e. a colloidal system consisting of a liquid dispersion medium contained in a spatial grid formed by connected particles of the dispersed phase. This is an undeniable advantage in terms of homogenization of materials having a multicomponent composition.

It is known [9] that there is a possibility to obtain ultra-lightweight corundum products of a complex configuration by selfhardening masses casting using sol-gel binders based on Ethyl Silicate. It is noted that the material obtained with the use of these binders has an increased high-temperature strength, heat resistance and resistance to cracking in comparison with traditional similar corundum products.

Synthetic silica powders obtained by means of the sol-gel method have found industrial application as a binding component in the production of various refractory products, coatings [10], as well as in the production of crucibles for melting silicon. The work [11] considers method for obtaining thin-film coatings based on mesoporous silicon dioxide by means of the sol-gel method in the presence of ethylene oxide oligomers and propylene oxide oligomers of different molecular weight. The method [12] has been proposed to use sol-gel synthesis of $\mathrm{SiO}_{2}$ products as binders for forming articles for various purposes, including wollaston ceramics, used to manufacture the refractory elements of foundry pattern equipment in aluminum industry.

In view of the foregoing, the purpose of this work was to improve Quartz Ceramics by modifying its structure with an activator based on Nanodispersed $\mathrm{SiO}_{2}$, obtained by means of sol-gel method.

\section{Experimental}

Quartz Tube Scraps were chosen as the main raw material for research.

Standard methods of investigation have been were used: moisture analysis of ceramic slurries in terms of loss in weight, grading curve analysis by means of sieve method, water absorption ability, porosity and density of calcined samples by hydrostatic weighing, mechanical strength of calcined samples on a hydraulic press [13].

The differential thermal analysis was performed using a synchronous thermal analyzer STA 449 F1 Jupiter [14].

Phase composition analysis of the fired samples was performed by means of X-ray phase analysis [15] using DRON-3M apparatus applying an X-ray tube with a copper anticathode.

The microstructures of the prototype preproduction models were examined by means of an optical microscope MBS-10 in reflected light with increase up to 32 times.

Nanodispersed silica is a very important component of any composite mixture due to its high reactivity $[13,14]$, which in its turn allows to significantly increase the strength of products, which include it as a component [15].

The works studying Quartz Ceramics [16] show that it is proposed to use a mixture of chlorides - Silicon Tetrachloride $\mathrm{SiCl}_{4}$ and Silane Trichloride $\mathrm{SiHCl}_{3}$ for synthesis of 
Table 1. Composition of the activators under research

\begin{tabular}{|c|c|c||}
\hline Component name & K3 & K7 \\
\hline Ethyl Silicate & 58,3 & - \\
Tetraethoxysilane & - & 82,5 \\
Water & 38.6 & 8.8 \\
$\mathrm{HCl}, 5 \%$ & 3,1 & 8,7 \\
\hline
\end{tabular}

high-purity quartz powder. However, Ethyl Silicate and Tetraethoxysilane are more accessible and less toxic components for preparation of the basis in the sol-gel method $[8,9]$.

The high cost of the high-purity quartz powder obtained by means of the sol-gel method does not allow to use it as a fullfledged substitution of traditional raw materials (Quartz Glass Scrap) in the Quartz Ceramics production. In this work, it is proposed to use quartz powder as an activator, which fills the voids between the quartz glass particles, thereby improving the material structure.

Ethyl Silicate ETS-40 and Tetraethoxysilane TEOS-28 were chosen as the Silicon Dioxide source for the activator under study. Ethyl Silicate is a mixture of polysilicic acids, it has the formula: $(\mathrm{RO})_{3} \mathrm{Si}\left[\mathrm{OSi}(\mathrm{OR})_{2}\right]_{4} \mathrm{OSi}(\mathrm{OR})_{3}$ and contains 40-41 wt $\%$ of $\mathrm{SiO}_{2}$. Tetraethoxysilane is an ether of Orthosilicic Acid and Ethyl Alcohol, has the formula: $\left(\mathrm{C}_{2} \mathrm{H}_{5} \mathrm{O}\right)_{4} \mathrm{Si}$ and contains 28-29 wt\% of $\mathrm{SiO}_{2}$.

These compounds cannot function as activators until hydrolysis process is carried out plus further heat treatment.

During the hydrolysis, ethoxyl groups $\left(\mathrm{C}_{2} \mathrm{H}_{5} \mathrm{O}\right)$ are replaced by hydroxyl groups $(\mathrm{OH})$ and this results in formation of sols in the form of colloidal acid solutions [8]. The hydrolysis products polymerize to form polymers of linear structure, in which the inorganic main chains of molecules are built from silicon and oxygen atoms (-Si-O-Si-) and encapsulated in the ethoxy groups.

Solutions with different physical and mechanical properties can be formed depending on the amount of water and the presence of a catalyst. In our case, the synthesis is planned to be carried out with a significant excess of water, which intensifies the process of sol formation and its transition into a gel [9].

To prepare the experimental activator compositions, gels were prepared (see Table 1) by vigorous mixing in a propeller crystallizer of Ethyl Silicate (K3 activator)

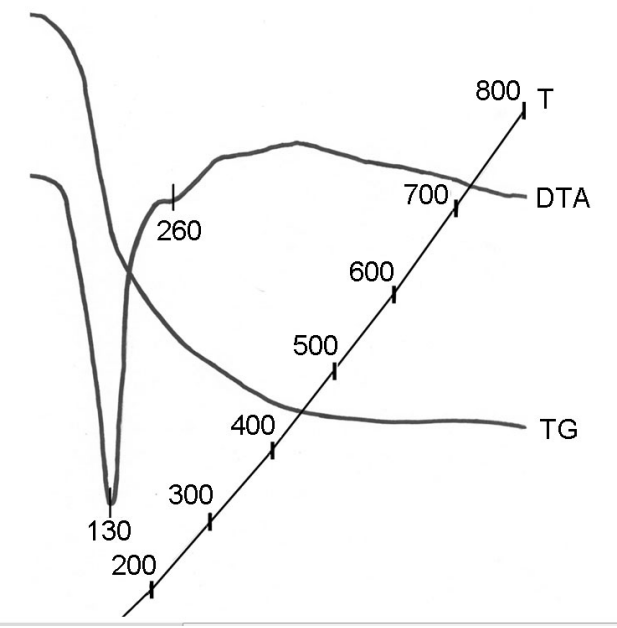

Fig. 1. Differential-thermal analysis of K3 activator.

or Tetraethoxysilane (K7 activator) with water in the presence of hydrochloric acid $\mathrm{HCl}$ chosen as a hydrolysis catalyst. At the same time, the duration of mixing and the visually visible changes that occurred during the preparation of sols were recorded. Mixing occurred for 8-12 $\mathrm{h}$ and after visually fixed homogeneity of the liquid compositions and viscosity of the systems, mixing was stopped to create the gel-processing conditions. The system passed completely into a gel-like state during the next 6-10 h.

Since the Quartz Ceramics, which was supposed to be treated by means of these activators, underwent firing, the influence of temperature increase on the character of the change in activator-binders was studied at the next stage of the work, and the phase composition of the products was determined.

\section{Results and discussion}

After gelling and drying (under natural conditions) $\mathrm{K} 3$ and $\mathrm{K} 7$ activators form strong monolithic agglomerate. Differentialthermal analysis of the $\mathrm{K} 3$ activator has been performed to determine the nature of their destruction; its results are shown in Fig. 1.

It can be seen from the above-mentioned thermogram that the temperature ranges of $100-350^{\circ} \mathrm{C}$ on the DTA curve provides two endo effects with maxima at 130 and $260^{\circ} \mathrm{C}$, the presence of which can be associated with the phased destruction of the polymer bonds in the activator composite structure. The endo effect at $575^{\circ} \mathrm{C}$, the presence of which could be expected due to modification trans- 

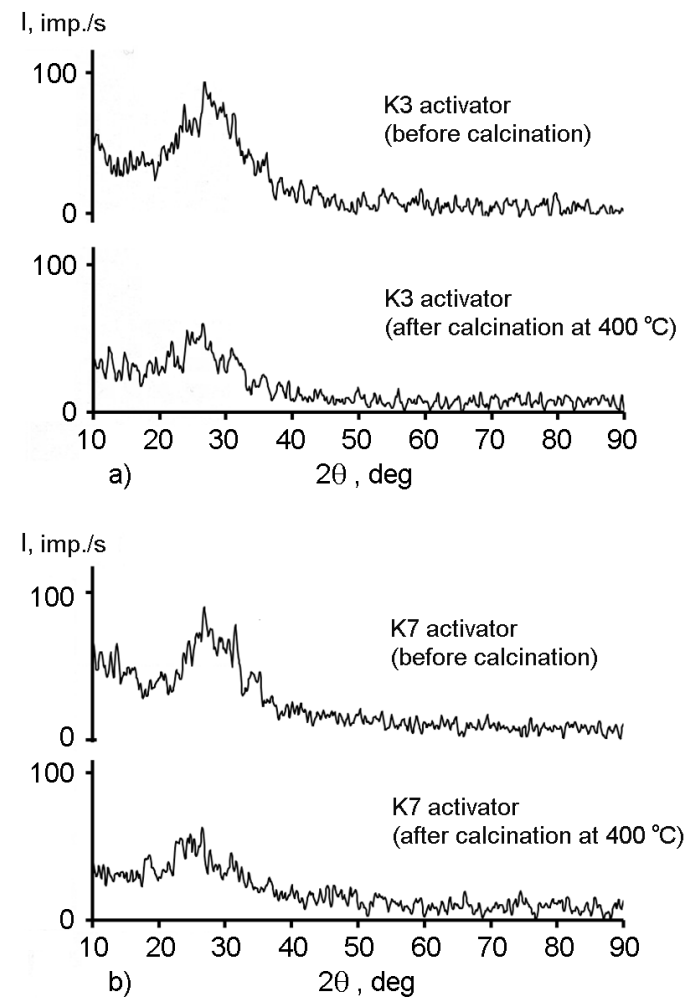

Fig. 2. X-ray patterns of K3 (a) and K7 (b) activators before and after calcination at $400^{\circ} \mathrm{C}$.

formation of $\beta$-quartz into $\alpha$ form, cannot be detected on the DTA curve, which happens due to the presence of silica in the amorphous state and is confirmed by the $\mathrm{X}$-ray phase analysis data (Fig. 2). When heated up to $400^{\circ} \mathrm{C}$, a constant loss of mass can be observed on the TG curve, which constitutes 58-59 wt. \% according to calculations [17]. It can be concluded that both Ethyl Silicate and Tetraethoxysilane can be used as the base gelling agent that adds $\mathrm{SiO}_{2}$ into the system, subject to the almost complete X-ray amorphism of the both activators before and after calcination (Fig. 2).

The experimental activators $\mathrm{K} 3$ and $\mathrm{K} 7$ obtained by the sol-gel method have been added into the quartz ceramic composition
Table 2. Properties of the investigated quartz ceramic slurries

\begin{tabular}{|c|c|c|c||}
\hline $\begin{array}{c}\text { Sample } \\
\text { No. }\end{array}$ & $\begin{array}{c}\text { Activator } \\
\text { No. }\end{array}$ & $\begin{array}{c}\text { Residue on } \\
\text { the sieve No. } \\
0063, \%\end{array}$ & $\begin{array}{c}\text { Moisture } \\
\text { content, \% }\end{array}$ \\
\hline basic & - & 0,20 & 27,8 \\
K3 & K3 & 0.21 & 28.1 \\
K7 & K7 & 0.20 & 28.7 \\
\hline
\end{tabular}

in an amount of 10 wt. \% during the next working stage. For this purpose, the Quartz Tube Scraps have been firstly grinded in an Alsing cylinder up to complete passing through a sieve No. 0063. Slurries for quartz ceramics samples casting have been prepared by wet fine grinding in a planetary mill.

The properties of the investigated Quartz Ceramics slurries are given in Table 2.

Prior to the samples casting, the slurries have been aged under periodical mixing of at least 3 days in order to facilitate the removal of the semi-finished product from the mold [18].

The samples have been fired at a temperature of $1250^{\circ} \mathrm{C}$ with a holding time at the maximum temperature during $1 \mathrm{~h}$. The results determining the properties of the fired Quartz Ceramics are given in Table 3 .

It has been experimentally established that when introducing experimental compositions of the investigated activators obtained by the sol-gel method, a significant change in the properties of the Quartz Ceramics is observed. Thus, there is a reduction in water absorption (up to 8.5-8.9\%) and open porosity (up to 14.7-15.3\%). At the same time, the apparent density of the samples increases up to $1.69-1.73 \mathrm{~g} / \mathrm{cm}^{3}$ and the compressive strength is up to $40-$ $44 \mathrm{MPa}$. This is due to formation of a denser packing of the sample structure due to the filling of the voids with Microparticles of Nanodispersed $\mathrm{SiO}_{2}$ obtained by the sol-gel method.

The microstructure of the experimental samples: basic and containing $10 \mathrm{wt}$. $\%$ of

Table 3. Results determining the properties of fired Quartz Ceramics

\begin{tabular}{|c|c|c|c|c||}
\hline Sample No. & $\begin{array}{c}\text { Water absorption } \\
\text { ability, \% }\end{array}$ & Opened porosity, \% & $\begin{array}{c}\text { Apparent volume } \\
\text { weight, g/sm }\end{array}$ & $\begin{array}{c}\text { Mechanical } \\
\text { Compressive } \\
\text { Strength, MPa }\end{array}$ \\
\hline basic & 15.4 & 23.8 & 1.55 & 33.2 \\
K3 & 8.5 & 14.7 & 1.73 & 44.0 \\
K7 & 8.9 & 15.2 & 1.69 & 40.0 \\
\hline
\end{tabular}




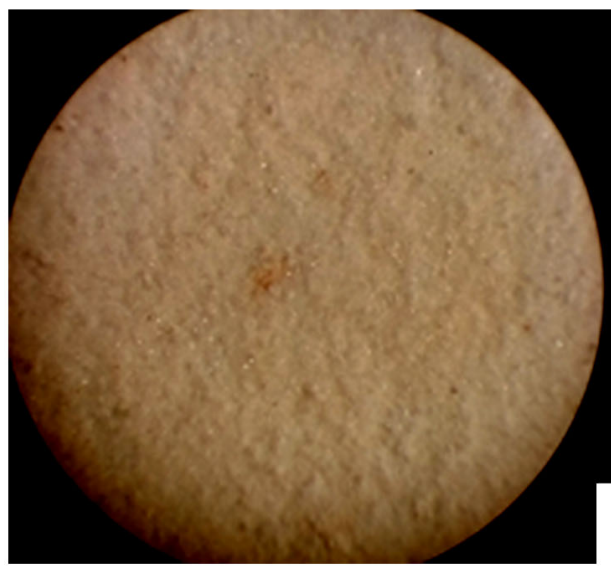

basic

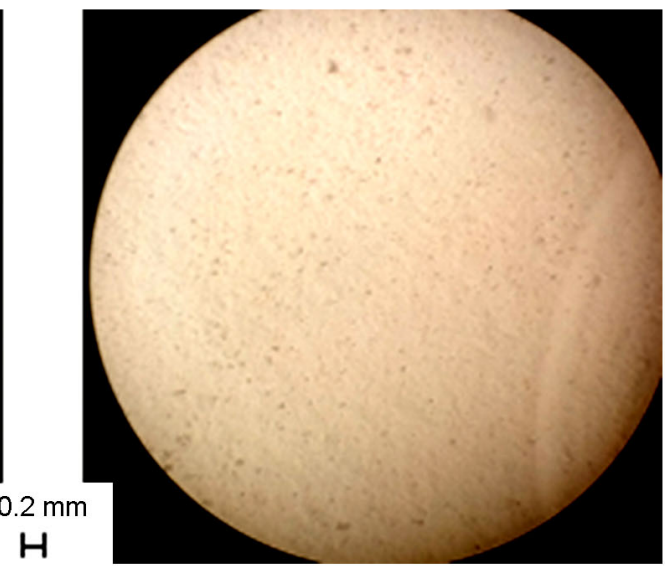

using $\mathrm{K} 3$ activator

Fig. 3. Microstructure of the samples after firing (polished microsection, reflected light).

the (K3) binder is shown in Fig. 3. The photograph clearly shows the porous, friable surface of the first sample, and the denser, smooth surface of the second sample.

The results of $\mathrm{X}$-ray phase analysis of the samples of pure Quartz Ceramics, and with addition of $\mathrm{K} 3$ activator, are shown in Fig. 4.

The given above information provides that the sample of Quartz Ceramics contains $\beta$-Cristobalite (diffraction maxima at 4.05 , $3.14,2.48,1.7 \AA$ ) as the main crystalline phase, which not only reduces the mechanical strength of products, but also significantly worsens their thermal stability, since abrupt heating and cooling makes this modification of silica to change its volume [3] and provokes internal stresses.

The crystalline phase cannot be practically identified in the samples with the K3 activator added.

\section{Conclusions}

Now it can be seen that, the adding activators that contain Nanodispersed Silica and obtained by means of sol-gel method into the Quartz Ceramics makes it possible to substantially increase its physical and mechanical properties.

The main condition to use such activators is the drying and firing of the gel at the temperature of up to $400^{\circ} \mathrm{C}$ with the purpose to remove the organic components, which otherwise will loosen the structure and, conversely, increase the water absorption ability of the Quartz Ceramic Samples.

It has been established that adding the activator in the amount of $10 \mathrm{wt}$ \% leads to the Quartz Ceramic Samples higher density: the water absorption ability of the

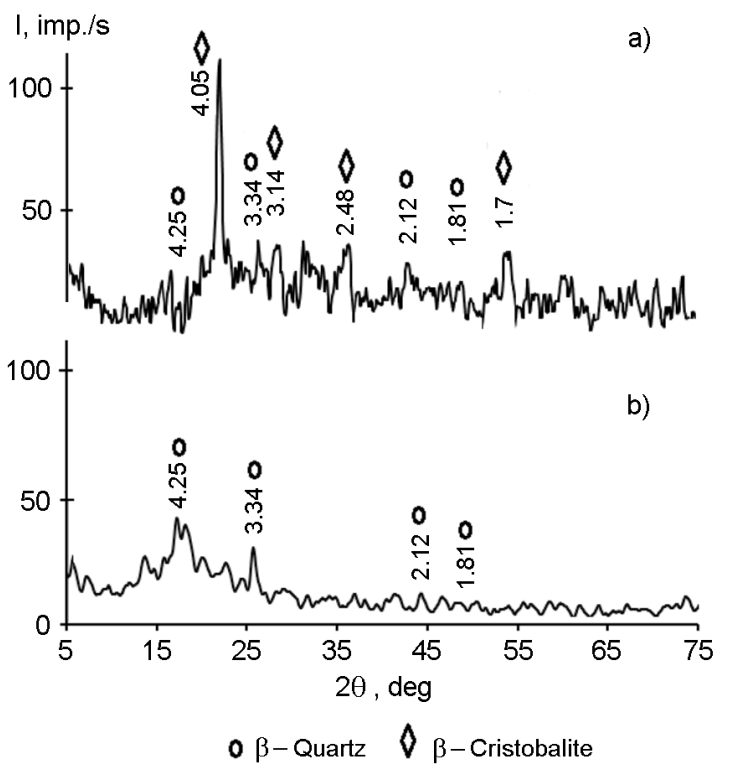

Fig. 4. X-ray patterns of Quartz Ceramic Samples: a - no additives, $\mathrm{b}-$ using K3 activator.

samples is reduced by $40-45 \%$. This is explained by the fact that the smallest particles of the $\mathrm{SiO}_{2}$ activator fill the voids between the larger particles of the crushed Quartz Glass Scrap, increasing the packing density within the sample structure.

\section{References}

1. Ye.I.Suzdaltsev, J.Refract. Techn. Ceram., 7-8, 21 (2009).

2. Yu.Ye.Pyvynskyi, Ye.I.Suzdaltsev, Quartz Ceramics and Refractories: Materials, their Properties and Application, Teploenerhetyk, Moscow (2008) [in Russian].

3. D.W.Richerson, Modern Ceramic Engineering: Properties, Processing, and Use in Design, 
CRC Press Taylor and Francis Group, Boca Raton (2006).

4. O.V.Zaichuk, O.A.Amelina, Zh.Voprosy Khimii $i$ Khimicheskoi Tekhnologii, 6, 63 (2017).

5. RU Patent 2515737 (2014).

6. RU Patent 2263090 (2005).

7. RU Patent 2436206 (2011).

8. H.D.Semchenko, I.Yu.Shutieieva, A.N.Butenko et al., Sol-gel Composition for Polyfunctional Application, Raduha, Kharkov (2011) .

9. H.D.Semchenko, Sol-gel Process in Ceramic Technology, Kharkov (1997) [in Russian].

10. RU Patent 2436206 (2011).

11. RU Patent 2368576 (2009).

12. N.S.Savchenko, Synthesis and Study of the Properties of Structural and Functional Materials based on Silicon Oxide, Siberian Federal University, Tomsk (2008) [in Russian].

13. Ya.I.Huzman, Workshop on Ceramics Technology, Building Materials, Moscow (2005) [in Russian].
14. O.P.Ryzhova, O.S.Mikhailyuta, O.O.Sihunov, Methods for Studying the Silicates Structure, Ukrainian State University of Chemical Engineering, Dnepropetrovsk (2012).

15. L.S.Zevin, G.Kimmel, Quantitative X-Ray Diffractometry, Springer-Verlag New York, Inc., New York (1995).

16. N.A.Shabanova, P.D.Sarkisov, Sol-gel Method. Nanodisperse Silica, BINOM. Laboratory of Knowledge, Moscow (2012) [in Russian].

17. N.A.Shabanova, P.D.Sarkisov, Fundamentals of Sol-gel Method of Nanodispersed Silica, Academic Book, Moscow (2004) [in Russian].

18. V.V.Potapov, A.N.Kashutin, A.A.Serdan et al., J. Nanoindustry, 2, 44 (2012).

19. A.F.Shymanskyi, O.I.Podkopaiev, M.N.Vasylieva et al., J.Siberian Federal University. Chemistry, 2, 307 (2009).

20. E.S.Khomenko, E.V.Karasik, V.I.Goleus, Functional Materials, 24, 593 (2017). 